\title{
Accreditation and Anticipatory Socialization to Doctoral Education in Kosovo
}

\author{
Nicholas Robert Stroup \\ University of Iowa, United States \\ Email: nicholas-stroup@uiowa.edu \\ Address: Center for Research on Undergraduate Education, University of Iowa, Iowa City, Iowa, United States
}

\section{Introduction}

In 2013, controversial accreditation regulations effectively mandated that Kosovo universities employ three PhD holders in every academic program to maintain accreditation (Kosovo Accreditation Agency [KAA] 2018; Ministry of Education Science and Technology [MEST] 2013; National Qualification Authority 2016). This requirement is difficult for higher education institutions (HEIs) to fulfill for two reasons. First, only about 70 students begin PhDs in Kosovo annually (MEST 2019). Second, undergraduate enrollment at Kosovo's universities has increased since the country's independence in 2008 (Danuza, Mehmeti, and Saqipi 2016), driving greater demand for PhD holders to teach across the disciplines. With only 0.1 percent of GDP allotted for scientific research (Muja 2015), initiatives to increase capacity for doctoral education must be strategically tied to national priorities. To help HEI leaders make strategic decisions to expand doctoral education in Kosovo, the research questions for this study are:

RQ1: What factors related to accreditation and legitimacy affect the delivery of doctoral education in Kosovo?

RQ2: How do these decisions affect the socialization of doctoral students?

\section{Accreditation and Legitimacy}

Despite legitimation efforts like the three-PhD accreditation rule, HEIs in Kosovo face scrutiny degree quality from supranational and national levels. At the supranational level, the European Quality Assurance Register for Higher Education (EQAR) accepted KAA as a registered agency in 2015, certifying KAA as a legitimate accreditor of degree programs in Europe. Three years later, following controversial education MEST actions affecting KAA (Limani 2017), EQAR removed KAA from the registry (Baliu 2019; EQAR 2018), leaving Kosovo's university graduates with credentials unrecognized throughout Europe.

Supranational legitimacy aside, the within-country legitimacy of credentials in Kosovo remain constantly debated. In 2019, nearly half of Kosovo's public universities lost KAA accreditation for all their programs (KAA 2019), which followed disaccreditation of dozens of around the country mere months before (Ademaj 2019). When the legitimacy of a credential is questionable - as codified by accreditation - prospective students cannot accurately assess the value of the programs they foresee themselves pursuing.

\section{Anticipatory Graduate Student Socialization}

Foreseeing what doctoral study entails is what Weidman, Twale, and Stein (2001) term anticipatory socialization. In anticipatory socialization, newcomers to doctoral study develop notional understandings about what doctoral pursuits will entail, relying upon idealized portrayals (12). Moreover, graduate socialization consists of dual processes of approaching graduate study and approaching a professional field (Golde 1998). The scarcity of terminal degree holders in Kosovo means prospective students have few embodied guideposts to help develop realistic expectations for 
their doctoral experience or their transition to professional life. As such, their anticipatory socialization may be idealistic, rather than well-informed.

\section{Data Collection}

To approach the two research questions, I implemented a QUAL+quan simultaneous design (Morse 1991). This approach situates doctoral socialization within the context of national attempts to increase capacity and meet accreditation demands for qualified academic staff. For the qualitative component, I implemented a basic qualitative study design (Merriam and Tisdell 2016) using semi-structured interviews with doctoral students in Kosovo, asking questions about why participants chose to pursue doctorates, perceptions of available choices in approaching doctoral study, and whether they believed their options were high-quality. Since data suggest mismatch between graduate programs and national needs in Kosovo (Muja 2015), I also asked about how doctoral students perceived this popular discourse in their decision to pursue a degree.

Several public-access digital repositories contribute quantitative data for this study. I collected labor market data from the Kosovo Agency of Statistics (2019) and staff and student headcount data about accredited public and private HEIs from 2002-2019 MEST reports (2019). Additionally, I used reports from the Organization for Improving the Quality of Education (ORCA), an education watchdog organization, to study academic staff members' credentials and outlets for their scholarly publications (ORCA 2019).

\section{Preliminary Findings}

Initial findings complicate perceptions of education-workforce mismatch when considering the role of accreditation. Related to RQ1, national and supranational accreditation and legitimacy concerns drove heightened scrutiny over the delivery of doctoral degrees and publications of doctoral students. As for RQ2, doctoral socialization in Kosovo is characterized by (1) barriers to pursuing academic and professional interests and (2) overlapping pressures of internationalization, funding, and identity. Those barriers and overlapping pressures affect student decisions about pursuing a doctorate in a climate where accreditation and legitimacy are constantly debated.

This study was partially funded by the University of Iowa Stanley Graduate Award for International Research (https:// international.uiowa.edu/students/awards/stanley).

\section{References}

Ademaj, Liridona. 2019. "University of Prishtina's Suspended Accreditation Programs." Prishtina Insight. February 6, 2019. https://prishtinainsight.com/university -of-prishtinas-suspended-accreditation-programs/.

Baliu, Doruntina. 2019. "Kosovo Accreditation Agency Axed from European Network Organization." Prishtina Insight. October 3, 2019. https://prishtinainsight.com/kosovo-accreditation-agency-axed-from-european-networkorganization/.

Danuza, Teuta, Fortuna Mehmeti, \& Blerim Saqipi. 2016. "EQF Referencing Report of the Kosovo National Qualifications Framework." Accessed May 24, 2019. https://akkks.rks-gov.net/uploads/kosovo _eqf_referencing_report_2016.pdf.

EQAR. 2018. "Exclusion of the Kosovo Accreditation Agency (KAA) from the Register." Accessed October 10, 2019. https://backend.deqar.eu/reports/EQAR/2018- 02_Exclusion_Decision_C22_KAA .pdf. 
Golde, Chris M. 1998. "Beginning Graduate School: Explaining First- Year Doctoral Attrition." New Directions for Higher Education 1998(101): 55-64.

Kosovo Accreditation Agency. 2018. "Accreditation Manual." Accessed October 10, 2019. http://www.akreditimiks.org/new/index.php/en/2015-08-31-11-59-45/guidelines-for-experts-new.

Kosovo Accreditation Agency. 2019. "List of AY 2019 Accredited Programs." Accessed October 10, 2019. http:// akreditimi-ks.org/docs/Downloads/ Accreditation/kshc20092019/kshc20092019.pdf.

Kosovo Agency of Statistics. 2019. "Labour Market” Accessed December 1, 2019. http://ask.rks-gov.net/sq/agjenciae-statistikave-te-kosoves/sociale/tregu-i-punes.

Limani, Lura. 2017. "Education Minister Fires Accreditation Agency Board Upon Haradinaj's Request." Prishtina Insight. September 26, 2017. https:// prishtinainsight.com/education-minister-fires-board-accreditation-agencyupon-haradinajs-request/.

National Qualification Authority. 2016. "EQF Referencing Report of the Kosovo National Qualification Framework for General Education, VET, and Higher Education." Accessed December 1, 2019. https://akkks.rksgov.net/uploads/kosovo_eqf_referencing_report_2016.pdf.

Merriam, Sharan B., \& Elizabeth J. Tisdell. 2016. Qualitative Research: A Guide to Design and Implementation. New York: John Wiley \& Sons.

Ministry of Education Science and Technology. 2013. "Administrative Instruction: No. 0212013 for Accreditation of Higher Education Institutions in the Republic of Kosova" Accessed December 1, 2019. https://masht.rksgov.net/uploads/ 2016/01/02-2013-ua-mbi-akreditimin-e-institucioneve.pdf

Ministry of Education Science and Technology. 2019. "Statistikat." Accessed December 1, 2019. https://masht.rksgov.net/en/statistikat.

Morse, Janice M. 1991. "Approaches to Qualitative-Quantitative Methodological Triangulation." Nursing research 40(2): 120-123.

Muja, Armend. 2015. “Evaluation Report: Kosovo Education Strategic Plan 2011-2016.” Accessed May 24, 2019. http://masht.rks-gov.net/uploads/2016/02/raport-vleresimi-psak-2011-2016-eng-web.pdf.

ORCA. 2019. "Publikimet.” Accessed October 10, 2019. http://orca-ks.org/sq/ publikimet/.

Weidman, John, Darla Twale, \& Elizabeth Stein. 2001. "Socialization of Graduate and Professional Students in Higher Education: A Perilous Passage?” ASHE-ERIC Higher Education Report 28 (3). 